\title{
Analisis Konsentrasi dan Fungsi Biaya Industri Tahu di Kabupaten Gunung Kidul Daerah Istimewa Yogyakarta
}

\author{
Oleh : Jaka Sriyana
}

\begin{tabular}{|l|l|}
\hline & $\begin{array}{l}\text { Jaka Sriyana, lahir di Sleman, 1. April 1967. Lulusan } \\
\text { Fakultas Ekonomi UGM Jurusan IImu Ekonomi dan } \\
\text { Studi Pembangunan (IESP). Sejak 1993 menjadidosen } \\
\text { tetap Fakultas Ekonomi UII Yogyakarta. Pekerjaan } \\
\text { sebelumnya sebagai staf peneliti pada Lembaga Studi } \\
\text { IImu-llmú KemasyarakatanuntukProyek Pengembangan } \\
\text { Industri Kecil (Small Bussines Service) atas biaya Bank } \\
\text { Dunia tahun 1993. Saat ini menjabat Kepala Bidang } \\
\text { Pengembangan Pusat Pengkajian dan Pengembangan } \\
\text { Ekonomi Islam (P3EI) FE-UII }\end{array}$ \\
\hline
\end{tabular}

-Latar Belakang Masalah

Sasaran jangka panjang pembangunan ékonomi antara läin, meningkatkan struktur ekonomi yang seimbang dalam arti struktur ekonomi dengan titik berat kekuatan industri yang didukung oleh bidang pertaniàn yang kuat dan mantap. Salah satu jenis industri yang langsung didukungi oleh sektor pertanian adalah industri tahu bahan baku utamanya adalah kedelai.

Sumbangan sektor industri terhadap total PDB menunjukkan peningkatkan yang cukup penting setiap tahun. Bahkan pada tahun 1991 kontribusi' sektor industri terhadap PDB adálah 22,2\% yang berarti sudah melebihi kontribusi dari sektör pertanian yang besamya $19,6 \%{ }^{1}$ Dilain pihak pertumbuhan produksi dari sub sektor industri pengolahan rata-rata tiap tahun belum menunjukkan' kenaikan yang mẹnggembirakạn. Begitu pula pertumbuhan produksi dari sub sektor industri kecil pada kenyataannya belum menunjukkań kenaikan yang meyakinkan di tengah periumbuhan ekonomi Indonesia yang relatif tinggi dalam kurun waktu sepuluh tahun terakhir ini. Kenyataan tersebut dapat. dilihat dari menurunnya kontribusi nilai produksi dari industri kecil terhadap nilai produksi sektor industri. Pada tahun 1984 kohtribusi nilai produksi industri kecil terhadap industri total adalah $27,14 \%$. namun angka ini menurun tajam dari tahun ke tahun berikutnya dan mencapai titik terendah pada tahun 1989 sebesar $4,8 \%{ }^{2}$

Untuk memperoleh hasil output industri yang optimal diperlukan syarat

1). Martani Husein, Dkk, "Pengembangan Usaha Berskala Kecil di Indonesia", Analisis CSiS No. 2, Maret - April 1993.

2). Ibid 
adanya efisiensi yang maksimal. Efisien merupakan masalah pokok dalam industri, termasuk industri tahu. Dan tingkat efisiensi tidak bisa terlepas dari struktur pasar baik pasar input maupun pasar output. ${ }^{3}$ Richard Caves mengatakan bahwà struktur pasar menentukan perilaku perusahaan dan perilaku perusahaan dapat menentukan kualitas performance perrusahaan. ${ }^{4}$ Untuk mengetahui struktur pasar dapat dilakukan denganmengukur derajatkonsentrasi pasar yang terjadi. Konsentrasi menunjukkan seberapa beśar segmen pemanfaatan faktor produksi tertentu agardiperolehoutput yang maksimäl.

Di Daerah Istimewa Yogyakarta sub sektor industri kecil merupakan primadona yang perlu mendapat perhatian yang lebih besar. Dari sub sektor ini berdasarkan laporan statistik daerah mampu menyumbang $27,25 \%$ dari total PDRB. Industri kecil di Daerah Istimewa Yogyakarta tersebar di seluruh daerah tingkat dua. Dipilihnya industri tahu di Kabupaten Gunungkidul sebagai obyek penelitian, karena komoditas tahu merupakan jenis makanan yang digemari oleh masyarakat Yogyakarta maupun daerah lain dan harganya dapat dijangkau oleh semua lapisan masyarakat. Sedangkan daerah Gunungkidul merupakan salah satu sentral industri tahu yang layak untuk dikembangkan hasil produksinya telah mampu menembus pasardi seluruh wilayah Gunungkidul.

\section{Perumusan Masalah}

Berdasarkan latar belakang masalah tersebut, dapat dirumuskan beberapa masalah sebagai berikut :-

1. Seberapa besar tingkat konsentrasi industri tahu di Kabupaten Gunung kidul ?

2. Apakah proses industri tah̆u diGunungkidul telah mencapai tingkat skala usaha yang optimal ?

\section{Tujuan Penelitian}

Penelitian ini memiliki tujuan :

1. Mengukur derajat konsentrasi industri tahu di Kabupaten Gunungkidul.

2. Mengetahui tingkatskala usaha industri tahu di Kab. Gunungkidul.

\section{Hipotesis}

1. Berdasarkan perbedaan kondisi antar unit industri tahu di Gunungkidul, maka diduga struktur pasar komoditas tahu di Gunungkidul terkonsentrasi.

2. Berdasarkan proses produksi yang sederhana, maka diduga bahwa industri tahu di Gunungkidul menghadapi fungsi biaya yańg menaik (Increasing Cost).

\section{Metodologi Penelitian}

\section{Populasi dan Sampel}

Penelitian ini merupakan penelitian empiris yang bertujuan untuk mengamati dan menganalisa tingkat konsentrasi dan fungsi biaya produksi industri tahu di - Kabupaten Gunungkidul. Untuk mendapatkan hasil penelitian yang diharapkan sesuai dengan, judul yang dikemukakan, populasi unit usaha perusahaan tahu yang dijadikan obyek penelitian ini adalah pengusaha tahu yang ada di Kabupaten Gunungkidúl. Para pengușaha tersebut berlokasi di hampir semua Kecamatan yang ada di Kabupaten Gunungkidul, yaitu Kecamatan Semin,

3).MuhidinSirait, "Konsentrasidan Efisiensi Industri Makanań di Jawa", Agroekonomika, FEUGM Edisi April 1990.

4), Clarkson, Kennetl $W$ and Roger $L ~ R$ Miller, "Industrial Organization : Theory, Evidencé and Public Policy" Mc Graw Hill Book Co, 1983. 
Ponjong, Semanu, Wonosari, Karangmojo, Nglipar, Playen.

Sampel yang digunakan dalah penelitian ini adalah seluruh populasi industri tahu yang ada. Adapun jumlah unit usaha yang diamati ada 42 unit usaha meliputi :

Kecamatan Wonosari : 19 unit usaha Kecamatan Semanu : 8 unit usaha Kecamatan Karangmojo : 3 unit usaha Kecamatan Semin : 4 unit usaha Kecamatan Ponjong : $\quad 4$ unit usaha Kecamatan Playen : 1 unit usaha Kecamatan Nglipar : 3 unit usaha Jumlah unit usaha Data yang digunakan

Data yang dianalisa adalah data semua perusahaan yang di Kabupaten Gunungkidul yang meliputi :

- Total produksi per hari

- Total pendapatan per hari

- Total biaya produksi per hari

- Data lain yang diperlukan sebagai pendukung

Untuk penelitian ini data yang dianalisis data rata-rata tiap hari dalam kurun waktu dua musim (musim kemarau 1993 dan musim panen 1994). Hal ini disebabkan pada kondisi kedua musim yang berbeda tersebut produksi tahu mengalami fluktuasi yang cukup besar. Dengan pengambilan sampel yang meliputi dua musim yang berbeda tersebut diharapkan akan diperoleh data yang valid.

\section{Metode Pengumpulan Data}

Pada penelitian ini data yang digunakan adalah data primer yang meliputi data-data ekonomi perusahaan tahu di seluruh Kab. Gunungkidul yang relevan untuk dianalisa. Adapun metode pengumpulan data dilakukan dengan cara :

1. Wawancara

Wawancara dilakukan dengan para pengusaha tahu tentang jumlah bahan baku yang digunakan, jumlah tenaga kerja dan jumlah produksi per hari, jumlah penghasilan per hari dan jumlah biaya yang dikeluarkan per hari.

2. Kuisioner

Kuisioner ini berisi daftar pertanyaan tentang hal-hal yang berkaitan dengan industri tahu.

3. Studi pustaka.

\section{Metode Analisa}

\section{Analisa terhadap konsentrasi industri tahu}

Struktur pasar menunjukkan atribut pasar yang mempengaruhi sifat dan proses persaingan. Salah satu unsur struktur pasar adalah konsentrasi, yaitu tinggi rendahnya derajat perusahaan yang ada mengadakan persaingan. Ada beberapa metode untuk mengukur konsentrasi pasar, yaitu kurva Lorenz, Indek Herfindahl dan Intersep Deviasi Rata-rata Relatif. Dalam penelitian ini akan menggunakan perhitungan rasio antara jumlah penawaran sejumlah pengusaha terbesardengan total penawaran yang dihasilkan oleh semua unit usaha. Disamping itu digunakan pula Indek Herfindahl untuk mengukur derajat konsentrasi tahu di Kab. Gunungkidul sebagai berikut : ${ }^{\mathrm{s}}$

$$
\begin{aligned}
& \mathbf{I H}=\sum_{\mathrm{i}-1}^{\mathrm{n}}(\mathrm{Xi} / \mathrm{T}) 2 \ldots \ldots \ldots(\mathrm{l}) \\
& \mathbf{I H}: \text { Indeks Herfindahl }
\end{aligned}
$$

5). Nurimansjah Hasibuan, "Ekonomi Industri : Persaingan, Monopoli dan Regulasi", LP3ES, Jakarta, 1993. 
$\mathrm{n}$ : Jumlah perusahaan

$\mathrm{X}$ : Jumlah penerimaan penjualan yang diterima oleh masing-masing perusahaan.

$\mathrm{T}$ : Nilai total pendapatan yang diterima oleh semua perusahan.

2. Analisis terhadap skala industri tahu Untuk mengetahui seberapa besar tingkat skala usaha industri tahu di Gunungkiduldigunakan pendekatan fungsi biaya produksi yang diderivasi dari fungsi produksi Coubb Douglass :

$\mathrm{Q}=A K^{\alpha} L^{\beta} \mathrm{N}^{\tilde{r}}$

$\mathrm{Q}=$ Jumlah nilai output $(\mathrm{Kg})$

$\mathrm{K}=$ Nilai modal (Juta)

$\mathrm{L}=$ Tenaga kerja (Orang)

$\mathrm{N}=$ Jumlah kedelai $(\mathrm{Kg})$

Jika total biaya dapat didefinisikan sebagai total pengeluaran untuk membayar faktor produksi, maka :

$\mathrm{C}=\mathrm{iK}+\omega \mathrm{L}+\mathrm{pN}$

$\mathrm{C}=$ Total biaya

$\mathrm{i}=$ Harga/bunga modal

$\omega=$ Upah tenaga kerja

$\mathrm{p}=$ Harga kedelai tiap kg.

Perusahaan melakukan prinsip minimisasi biaya untuk suatu tingkat keluaran output tertentu, maka penggunaan faktor produksi dapat dilakukan dengan minimisasi fungsi Langrangian sebagai berikut :

$\mathrm{Y}=\mathrm{iK}+\omega \mathrm{L}+\mathrm{rN}+\Gamma(\mathrm{Q}-\mathrm{AK} \alpha \mathrm{L} \beta \mathrm{N} \Gamma)$

Kondisi untuk maksimisasi adalah :

$\mathrm{dY} / \mathrm{dK}=\mathrm{i}-\tau \alpha A \mathrm{~K}^{\alpha-1} \mathrm{~L}^{\beta} \mathrm{N}^{\mathrm{r}}=0$

$\mathrm{dY} / \mathrm{dL}=\mathrm{w}-\tau \beta A K \alpha \mathrm{L}^{\beta-1} \mathrm{~N} \Gamma=0$

$d Y / d N=p-\tau \Gamma A K^{\alpha} L^{\beta} N^{\Gamma-1}=0$

$\mathrm{dY} / \mathrm{d}=\mathrm{Q}-\mathrm{AK}^{\alpha} \mathrm{L}^{\beta} \mathrm{N}^{\Gamma}=0$

Dengan cara substitusi persamaan (4) terhadap fungsi biaya dan menyelesaikan secara matematis akan diperoleh bentuk fungsi biaya $:^{6}$

$\mathrm{C}=\mathrm{A} \cdot \mathrm{AQ}^{\mathrm{d}}$

Model matematis tersebut dapat ditulis dalam model ekonometri sebagai berikut : $\log C=\log A+d \log Q+e \ldots$ (7) $d=1 /(\alpha+\beta+\Gamma)$

Tingkat skala usaha ditunjukan oleh besar kecilnya nilai d. Angka tersebut mencerminkan adanya tiga kemungkinan Return to scale :

- Jika $\alpha+\beta+\Gamma .>1$ mencerminkan adanya keadaan 'increasing retum to scale' yang berarti kelipatan output lebih besar dari kelipatan masing-masing input.

- Jika $\alpha+\beta+\Gamma=1$ mencerminkan adanya keadaan 'constant retum to scale' yang berarti kelipatan output sama dengan kelipatan masing-masing input.

- Jika $\alpha+\beta+\Gamma<1$ mencerminkan adanya keadaan 'decreasing return to scale' yang berarti kelipatan output lebih kecil dari kelipatan masing-masing input.

Dengan menggunakan metode Ordinary Least Square (OLS) kita dapat menaksir nilai masing-masing parameter dari persamaan 7 untuk mengetahui tingkat efisiensi industri tahu di Gunungkidul.

\section{Hasil Penelitian}

\section{Hasil Analisa Konsentrasi}

Untuk mengukurkonsentrasi industri pada sentra industri kecil tahu di Gunungkidul digunakan rasio proporsi produksi tahu dari sejumlah pengusaha $(4$, 8 dan 10perusahaan) terhadap total produksi yang dihasilkan oleh seluruh pengusaha pabrik tahu yang ada di Gunungkidul dan

6). Marc Nerlove, "Estimation and Identification of Coubb Douglas Production Function", Rand Mc. Nally Co, Chicago 
Indeks Herfindahl, yang diformulasikan diamati dalam hal ini adalah variabel oleh Omis C. Herfindahl. Variabel yang penerimaan pendapatan perusahaan.

Tabel 1 : Datà Industri Kecil Tahu di Gunungkidul Tahun 1994

\begin{tabular}{|c|c|c|c|c|c|c|c|}
\hline No. & $\begin{array}{c}\text { Tenaga } \\
\text { kerja }\end{array}$ & & $\begin{array}{c}\text { Kg.Kedelail } \\
\text { hari }\end{array}$ & $\underset{\substack{\text { hari } \\
\text { hahu/ }}}{\text { Taho }}$ & $\begin{array}{c}\text { Rev.Tot } \\
\text { hari } \\
(000)\end{array}$ & & $\begin{array}{c}\text { B.Prod/ } \\
\text { hari } \\
(000)\end{array}$ \\
\hline 1 & 5 & & 200 & 490 & 442 &. & 348,8 \\
\hline 2 & 4 & & 150 & 367,5 & 331 & . & 261,7 . \\
\hline 3 & 3 & & 180 & 441 & 403 & & 313,9 \\
\hline 4 & 3 & & 150 & 367,5 & 332 & & 261,7 \\
\hline 5 & 3 & & 200 & 490 & 442 & & 348,8 \\
\hline 6 & 3 & & 160 & 392 & $\cdot 351$ & & 279,2 \\
\hline 7 & 12 & & 350 & 857,5 & 773 & & 610,7 \\
\hline 8 & 4 & & 220 & 539 & 481 & & 383,7 \\
\hline 9 & 5 & & 210 & 515 & 462 & . & 366,2 \\
\hline 10 & 7 & & 300 & 735 & 663 & & 523,3 \\
\hline 11 & 5 & & 250 & 612,5 & 552 & & 436 \\
\hline 12 & 3 & & 125 & 306 & 270 & & 218 \\
\hline 13 & 3 & . & 100 & 245 & 221 & & 174,4 \\
\hline 14 & 15 & & 400 & 900 & 887 & & 697,6 \\
\hline 15 & 6 & & 250 & 612,5 & 553 & & 436 \\
\hline 16 & 5 & & 260 & 637 & 572 & & 453,4 \\
\hline 17 & 6 & & 200 & 490 & 441 & & 348,8 \\
\hline 18 & 7 & . & 300 & 735 & 663 & r & 523,3 \\
\hline 19 & 5 & & 200 & 490 & 441 & & 348,8 \\
\hline+20 & 3 & & 100 & 245 & 223 & & 175 \\
\hline 21 & 3 & & 120 & 294 & 260 & & 209 \\
\hline 22 & 4 & & 210 & 515 & 462 & . & 365,2 \\
\hline 23 & 3 & & 150 & 367,5 & 331 & & 261,7 \\
\hline 24 & 4 & 、 & 200 & 490 & 443 & & 348,8 \\
\hline 25 & 3 & & 160 & 391 & 349 & & 278,8 \\
\hline 26 & 3 & $=$ & 100 & 245 & 222 & & 174,6 \\
\hline 27 & 3 & & 100 & 245 & 221 & & 174,4 \\
\hline 28 & 3 & & 175 & 428 & 381 & & 305 \\
\hline 29 & 3 & & 100 & .245 & 222 & & 174,4 \\
\hline 30 & 4 & & 200 & 490 & 445 & & 348,8 \\
\hline 31 & 3 & & 100 & 245 & 224 & & 176,4 \\
\hline 32 & 3 & & 150 & $367 ; 5$ & 333 & & 261,7 \\
\hline 33 & 3 & & 110 & 269 & 241 & & 191,8 \\
\hline 34 & 3 & & 150 & 367,5 & 335 & & 261,7 \\
\hline 35 & 3 & & 100 & 245 & 225 & & 174,4 \\
\hline 36 & 3 & & 120 & 264 & 265 & & 174,4 \\
\hline 37 & 3 & & 75 & 183,75 & 166 & & $.130,8$ \\
\hline 38 & 3 & & 100 & 245 & 223 & & 173,9 \\
\hline 39 & 4 & & 150 & 367,5 & 334 & & 261,7 \\
\hline 40 & 3 & & 110 & 270 & 242 & & 192 \\
\hline 41 & 3 & & 100 & 245 & 223 & & 174,9 \\
\hline 42 & 3 & & 80 & 196 & 176 & & 139,5 \\
\hline
\end{tabular}

Sumber : Diolah dari Data Primer 
Dari 42 unit usaha diperoleh angka konsentrasi 10 perusahaan terbesar yaitu sebesar 0,38 atau $38 \%$. Jadi jumlah produksi dalam suatu pasar sebanyak 38\% dikuasai oleh sepuluh perusahaan terbesar.

Hasil perhitungan sampai. ke 8 terbesar yang menguasai pasar diperoleh angka konsentrasi industri sebesar $28,1 \%$. Dengan melihat batașan yảng dikemukakan oleh Cark Keysan dan Donal F. Tumer, (1959) maka angka ini berarti bahwa pada sentra industri kecil tahu di Gunungkidul penyebaran industrinya tidak terkonsentrasi.

1. Hasil perhitungan dengan menggunakañ 4 perusahaan terbesar diperoleh angka proporsi sebesar $18,6 \%$. Dại hasil angka ini menunjukkan bahwa 4 perusahaan tahu -terbesar yang beroperasi di Kabupaten Gunungkidul menghasilkan total produksi sebesar 18,6 persen dari seluruh hasil produksi tahu yang dihasilkari oleh semua perusahaan tahu yang ada di Gunungkidul.

Seorang ahli marketing, Joe. S. Bain (1954) membagikriteria tingkat ḱkonsentrasi industri yang berbentuk oligopoli kedalam 4 tipe, yaitu :
Dari batasan tersebut, maka hasil analisis konsentrasi industri tahu di Kabupaten Gunungkidul menunjukkan bahwa struktur industri tahu tersebut tidak terkonsentrasi (bukan termasuk tipe oligopoli). Dengan kata lain struktur pasar komoditas tahu di Gunungkidul memiliki derajat kemerataan yang tinggi.

Analisis terhadap tingkat konsentrasi industri tahu dengan menggunakan indèks Herfindahl memberikan hasil yang tidak jauh berbeda. Dari jumlah 42 perusahaan tahu yang ada 'memberikan hasil angka Indeks Herfindhal (IH) sebesar :

\begin{tabular}{|c|c|c|}
\hline $\begin{array}{c}42 \\
\text { IH : }:\end{array}$ & xi & $2 \begin{array}{c}x=\text { Penerimaan masing } \\
\text { masing produsen }\end{array}$ \\
\hline $\begin{array}{l}i=1 \\
: 0,0257\end{array}$ & $T$ & \\
\hline
\end{tabular}

Sesuai déngan formula yang dikemukakanioleh Herfindhal keadaan yang merata sempurna untuk 42 perüsahaan adalah: $1 / 42=0,0238$. Dengan demikian angka IH yang ditemukan dari penelitian ini tidak jauh berbeda dengan angka kemerataan sempuma untuk 42 perusahaan. -Dengan demikian dapat dikatakan, bahwa

Tabel 2. Tipe Oligopoli

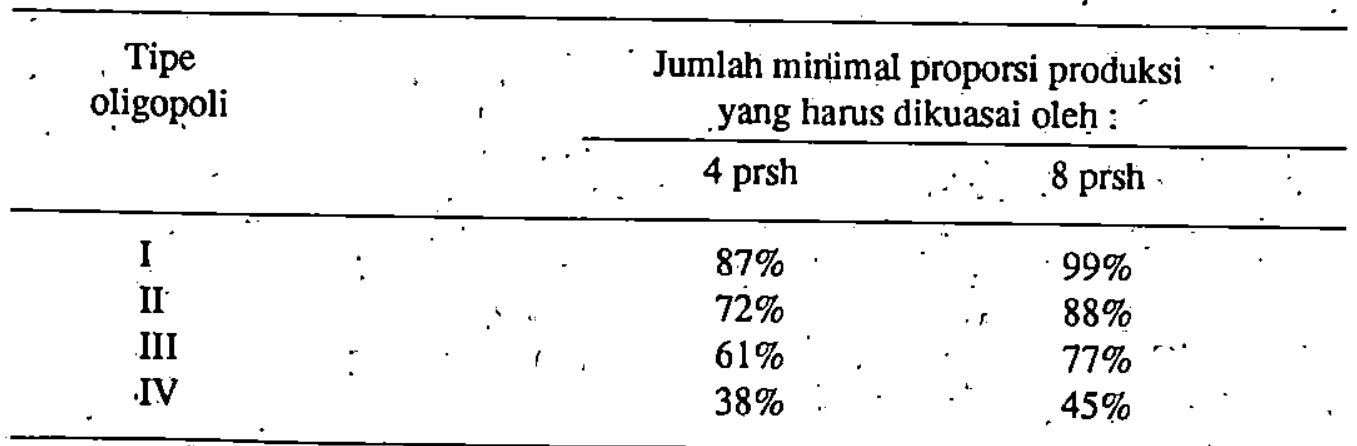

Sumber : Nurimañsyah Hị Ekonomi Industri, 1993 
struktur industri tahu di Kabupaten Gunungkidul tidak terkonsentrasi.

\section{Hasil Analisa Fungsi Biaya}

Keseluruhandatayang akan dianalisa merupakan data cross, section dengan jumlah sampel sebanyak 42 unitusaha yang - berada di daerah Kab. Gunungkidul. Variabel yang dianalisa untuk menemukan fungsi biaya industri tahu adalah total biaya variabel masing-masing unitusaha tiaphari dan totál produksi tahu masing-masing unit usaha tiap hari.

Dengan menggunakan alat analisis regresi linierdenganmetode Ordinary Least Square diperoleh persamaan regresi sebagai berikut (lihat lampiran) :

$$
\begin{aligned}
\log C= & 0,2265+1,14 \log Q: \\
& (0,31) \cdot(9 ; 25) \\
R^{2}= & 0,68 \\
F & =85 \\
D W= & 2,032
\end{aligned}
$$

Angka dalam kurung menunjukkan nilai $t$ statistik. Hasil perhitungan tersebut memberikan hasil yang memuaskan. Tanda koefisien regresi sesuai dengan yang diharapkan, yaitu bertanda positip. Apabila dilihat dari tanda yang menyertai keofisien regresi maka dapat dikatakan bahwa tanda positip yang menyertai koefisien regresi $Q$ berarti apabila jumlah produksi meningkat maka jumlah biaya untuk produksi akan meningkat pula.

Berdasar hasil perhitungan t-test dapat dikatakan bahwa jumlah produksi secara individual mampu mempengaruhi jumlah biaya.l Demikian pula secara. bersama-sama variabel penjelas mampu menjelaskan banyak sedikitnya biaya produksi pada industri tahu di Kab. Gunungkidul, hal ini dapat dilihat dari hasil

\section{Fisher test.}

Hasil pengujian lain adalah koefisien determinasi $\left(R^{2}\right)$, yang berfungsi mengukur prosentase total variasi dalam $C$ yang dijelaskan oleh model regresi. Berdasar perhitungan yang ada, $R 2$ 'sebesar 0,68 dapat dikatakan bahwa penggunaan model regresi dapat memberikan hasil yang baik. Angka ini menunjukkan bahwa $68 \%$ variasi perubahan besarny'a biaya produksi ditentukan oleh variasi perubahan hasil produksi:

Untukmeñdapatkan fungsi biayakita dapat mengubah persamaan regresi dalam bentuk log ke persamaan biaya, yaitu sebagai berikut $n$ :

$$
\mathrm{C}=0,2265 \mathrm{Q}^{1,14}
$$

Dengan melihat nilai dari ukuran skala yang besanrya sama dengan 1,14 menunjukkan bahwa industri tahu di Kabupaten Gunungkidul berada pada kondisi Decreasing Return to Scale, yang berarti bahwa pengusaha sudah berada pada kondisi optimal dan tidak' memperoleh manfaat skala ekonomi.

Dari bentuk fungsi total tersebut dapat kita temukan besarnya fungsi biaya marginal (MC), yaitu :

$$
\begin{aligned}
\mathrm{MC} & =\mathrm{dC} / \mathrm{dQ} \\
& =\mathrm{d}\left(0,02265, \mathrm{Q}^{1,14}\right) / \mathrm{dQ} \\
& =0,258 \mathrm{Q}^{0,14}
\end{aligned}
$$

Fungsi ini menunjukkan bahwa kondisi industri tahu berada pada kondisi biaya marginal yang menaik. Hal ini mengindikasikan bahwa industri tahu tidak berada pada keadaan yang efisien.

Berdasarkan fungsi biaya total tersebut pula kita turunkan biaya rata-răta produksi tahu (AC) yaitu : 


$$
\begin{aligned}
A^{C} & =C / Q \\
& =\frac{0,2265 Q^{1.14}}{Q^{\prime}} \\
& =0,2265 Q^{0.14}
\end{aligned}
$$

Dari fungsi biaya rata-rata ini menunjukkan bahwa kondisi industri tahu berada pada keadaan biaya rata-rata yang menaik. Dengan demikian semakin besar jumlah output akan menyebabkan meningkatnya biaya produksi tiap setahun unit produksi. Keadaan ini tentu saja tidak menguntungkan bagi pengusaha. Kurva fungsi biaya rata-rata (AC) dapat kita lihat pada gambar.

Untuk lebih memperjelas pembahasan dan pemahaman mengenai kondisi industri tahu di Kabupaten Gunungkidul dapat kita lakukan dengan menggambarkan bentuk fungsi biaya terśebut kedalam satu set kurva biaya sebagai berikut :

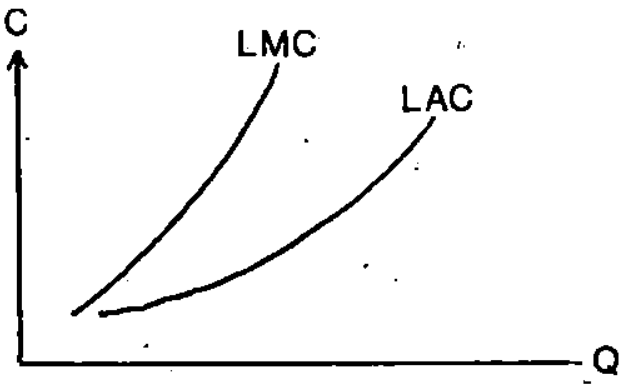

Gambar 1 : Kurva Fungsi Biaya jangka Panjang Industri Tahu di Kab. Gunungkidu!

Dari gambar 1. dapat diketahui bahwa bentuk kurva biaya rata-rata dan biaya marginal berlereng positip. $\mathrm{Hal}$ ini menunjukkan bahwa semakin tinggi output diproduksi akan mengakibatkan pertambahan biaya perunit. Dengan kata lain industri tahu di Kabupaten Gunungkidul berada pada kondisi Decreasing return to scale. Kondisi ini menunjukkan pula bahwa perusahaan tidak mendapatkan manfaat kehematan skala jika total produksi ditingkatkan. Hal ini menunjukkan pula terjadinya inefisiensi pada proses produksi. Kondisi ideal yang terjadi adalah jika proses produksi berada pada kondisi biaya ratarata minimum. Namun hal ini jarang terjadi. Keadaan yang umum terjadi pada industri pengolahan adalah kondisi yang dihadapi perusahaan adalah increasing return to scale, sehingga pengusaha mendapatkan penghematan skala jika total produksi dinaikkan. Dengan kata lain kondisi perusahaan berada pada tingkat efisiensi yang tinggi, biaya rata-rata yang dihadapi berlereng negatip.

Kondisi yang terjadi pada industri tahu di Gunungkidul tersebut disebabkan oleh beberapa hal, yaitu :

1. Pengaruh lokasi perusahaan

Pada kenyataannya hampir semua unit usaha tersebar diberbagai daerah yang relatif jauh. Keadaan demikian menyebabkan biaya angkut faktor produksi maupun biaya pemasaran relatif tinggi.

2. Pengaruh proses produksi

Proses produksi yang terjadi pada masing-masing unit usaha masih menggunakan peralatan yang sederhana dan teknologi yang bersifat tradisional. Hal ini menyebabkan biaya produksi tiap unit untuk tiap periode waktu relatif tinggi.

3. Pengelolaan unit usaha

Usaha industri tahu yang ada di wilayah Gunungkidul hampirsemuanya dikelola secara sederhana dan belum 
menggunakan cara-cara yang modem sehingga pengelolaan proses produksi maupun keuangan tidak efisien.

Sehubugan dengan kasus industri tahu di Kabupaten Gunungkidul yang ditemukan dalam penelitian ini, maka efisiensi bagi perusahaan, skala perusahaan perlu ditingkatkan.

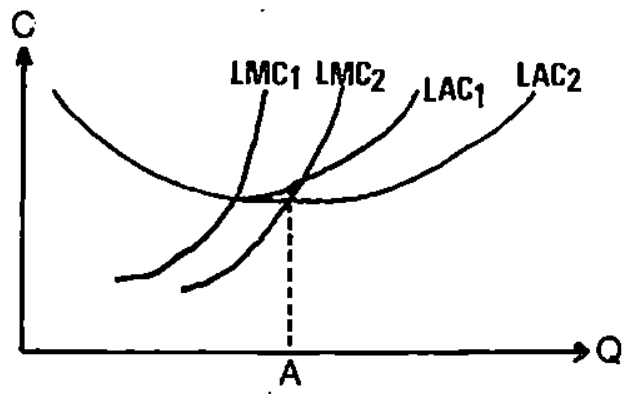

Gambar 2 : Pergeseran Fungsi biaya Perusahaan Untuk Mencapai Kondisi Optimum

Untuk lebih jelasnya dapat dilihat pada gambar 2. Misalkan total produksi berada pada titik $A$, perusahaan tidakefisien, karena perusahaan berada pada skala dimana kurva biaya yang dihadapi adalah LMCl dan LACl. Oleh karena itu untuk meningkatkan efisiensi skala perusahaan perlu diubah ke skala yang memiliki kurva biaya LAC2, LMC2 dan LAC2. Pada kondisi ini perusahaan menghadapi skala optimum dan tingkat biaya rata-rata minimum.

Untuk mengubah skala produksi atau menggeserkurva biaya darikondisi pertama menuju kondisi kedua untuk memperoleh

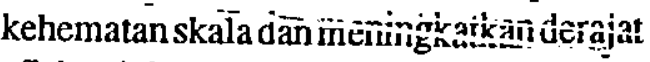
efisiensi dapat dilakukan dengan cara :

1. Dengan memperluas skala usaha, mengingat pangsa pasar untuk komoditas tahu masih dapat diraih dengan cara diferensiasi harga dan diferensiasi produk, yaitu dengan cara menjual tahu dengan berbagai ukuran serta berbagai macam dan bentuknya sesuai dengan kondisi pasar yang dijadikan tujuan pemasaran. Disamping itu perluasan pangsa pasar hingga di luar daerah Gunungkidul masih sangat memungkinkan mengingat daerah diluar Kabupaten Gunungkidul seperti Kabupaten Bantul, Sleman, Klaten dan Daerah Istimewa Yogyakarta merupakan pasar yang sangat potensial bagi pemasaran komoditas tahu, mengingat komoditas tahu merupakan salah satu jenis makanan yang digemari oleh masyarakat di daerah tersebut.

2. Dengan mengubah proses produksi tahu dengan memakai teknologi yang lebih modem. Salah satu cara yang bisa ditempuh adalah dengan mengganti mesin pengolah berupa mesin diesel dengan motorlistrik yang menggunakan energi listrik sebagai tenaga penggeraknya. Dengan demikian akan memerlukan biaya operasi maupun biaya pemeliharaan yang lebih rendah. Perubahan ini lebih dikenal dengan istilah "Change over".

3. Peningakatan kualitas sumber daya manusia sebagai pengelola industri tahu dengan jalan mengikuti kursus-kursus dan pelatihan pengelolaan industri tahu. Disamping itu pengusaha perlu menambah wawasan dalam bidang penggunaan teknologi modern untuk proses produksi tahu. Hal ini dapat ditempuh dengärinaliakukakan kunjungan kepada pengusaha didaerah lain yang sudah lebih maju. Sebagai contoh adalah 
sentra industri tahu di Ngestiharjo Bantul. Juga perlu mengadakan kunjungan sentra lingkungan industri kecil yang merupakan tempat pembuatan peralatan industri kecil. Dengan adanya tambahan wawasan tersebut, maka pengusaha akan lebih temotivasi untuk mengelola usahanya dengan lebih profesional yang pada akhirnya akan Icbih meningkatkan kemampuan usahanya, baik dari segi teknis produksi maupun dari kemampuan bersaing dengan pengusaha lainnya. Dengan demikian akan bcrakibat pada semakin kecilnya biaya opcrasional usahanya.

\section{Kesimpulan dan Saran}

Kesimpulan

Bcrdasarkan hasil analisis terhadap konsentrasi dan fungsi biaya produksi industri tahu cli Kabupaten Gunungkidul, maka dapal dihasilkan kesimpulan scbagai berikut :

1. Dari analisiṣ tcrluadap 42 unil usaha tahu yang beroperasi di seluruh Kabupalen Gunungkidul memberikan hasil bahwa derajal kelidakmerataan struktur pasar komodilas lahu rendah. Indeks Herfindhal yang diperolch adalah 0,0257 . Angka ini lidak berbeda jauh dengan angka kemerataan ideal untuk 42 perusahaan yang beroperasi di suatu pasar, yaitu 0,0238. Derajat ketidakmerataan yang rendah tersebut menunjukkan bahwa struktur pasar memiliki pola distribusi penghasilan yang merata pada semua unit usaha yang ada.

2. Hasil analisis terhadap fungsi biaya produksi industri tahu memberikan hasil bahwa proses produksi tahu di wilayah Kabupaten Gunungkidul menghadapi kurvabiaya rata-rata dan biaya marginal yang semakin menaik. Dengandemikian semakin banyak jumlah unit output yang diproduksi akan mengakibatkan biaya rata-rata tiap unit yang harus dikeluarkan oleh pengusaha semakin meningkat. Kondisi ini menunjukkan bahwa pengusaha berada pada situasi "Decreasing retum to scale". Ini berarti bahwa perusahaan sudah berada pada kondisi yang optimal. Perusahaan sudah tidak memiliki kehematan ekonomis. Keadaan yang demikian menunjukkan bahwa proses produksi tahu di Kabupaten Gunungkidul tidak efisien, baik secara ekonomis maupun secara teknis produksinya.

3. Keadaan yang menyebabkan terjadinya ketidakefisienan produksi tahu adalah :

a. Lokasi perusahaan yang berjauhan dan terpencil sehingga biaya angkut untuk bahan baku dan bahan pendukung relatif mahal.

b. Proses produksi yang masih menggunakan peralatan yang sederhana serta kualitas sumber daya manusia yang sangat rendah. Hal ini akan mengakibatkan biaya produksi tiap unit tiap periode waktu menjadi mahal.

c. Pola pengelolaan unit usaha yang niasih menggunakan cara-cara tradisional serta belum dipisahkannya antara pengelolaan keuangan perusahaan dengan -pengelolaan keuangan rümah tangga. Belum dilakukannya pembukuan secara teratur.

d. Daerah pemasaran yang relatif jauh 
sehingga biaya angkut maupun biaya pemasaran lainnya menjadi mahal.

4. Berdasarkan hasil penelitian tersebut maka perlu dilakukan usaha-usaha untuk meningkatkan derajat elisiensi industri tahu di Kabupaten Gunungkidul.

\section{Saran-saran}

Dari hasil analisis pada penelitian ini, maka ada beberapa saran yang perlu dikemukakan kepada pengusaha tahu maupun kepada pihak lain yang terkait, terutama Departemen Perindustrian dalam rangka untuk meningkatkan kemampuan maupun efisiensi industri tahu di Gunungkidul.

Untuk meningkatkan kemampuan dan efisiensi industri tahu tersebut dapat dilakukan dengan carạ :

'. Peningkatan skala usaha unit usaha yang relatif kecil menjadi unit usaha yang lebih besar, mengingat pangsa pasar masih dapat diusahakan untuk diperluas.

2. Proses produksi tahu hendaknya diubah dari cara-cara tradisional menuju caracara yang lebih modem dengan jalan menggunakan teknologi modern (Change over).

3. Peningkatan kualitas sumber daya manusia pengelola unit usaha tersebut dengan jalan mengikuti pelatihan tentang manajemen industri kecil.

4. Pengelolaan unit usaha dengan menggunakan cara-cara yang lebih modem, pemisahan antara manajemen rumah tangga damn manajemen unit usaha.

5. Pemerintah daerah dalam hal ini Departemen Perindustrian hendaknya giat melakukan penyuluhan dan pelatihan kepada para pengusaha tahu tentang pemanfaatan teknologi modem dalam proses produksi tahu. Disamping itu perlu juga dilakukan penyuluhan tentang manajemen industri kecil modem.

\section{Daftar Pustaka}

Clarckson, Kenneth W and Rogger L.M. Miller, "Industrial Organization: Theory, Evidance Policy", Mc. Graw Hill Book Co, 1983.

Irsan Ashary Sáleh, "Industri Kecil: Sebuah Tinjauan dan Perbandingan", LP3ES. Jakarta.

Lembaga Studi Ilmu Kemasyarakatan (LSIK), Laporan Tahunan Program Kerja: Laporan Tahun I, Yogyakarta, 1993.

Marc Nerlove, "Estimation and Identification of Coubb Douglass Production Function". Rand Mc Nally Co., Chicago.

Martani Husein dkk. "Konsentrasi Usaha Berskala Kecil di Indonesia". Analisis CSIS, No.2, Maret - April 1993.

Muhidin Sirait, "Konsentrasi dan EfisiensiIndustri Makanan di Jawa". Agroekonomika,FE-UGM. April 1990. Nurimansyah Hasibuan dan Bambang Triguno, "Efisiensi dalam Distribusi: Beberapa "Kasus Komoditi", dalam Mubyarto dan Edy Suandi Hamid (penyunting), "Meningkatkan Efisiensi Nasional", Kumpulan Hasil Seminar, BPFE-UGM, Yogyakarta, 1987.

Nurimansyah Hasibuan, "Ekonomi Industri: Persaingan, Monopoli, dan Regulasi", LP3ES, Jakarta, 1993.

Soemitro Djojohadikusumo,"Perdagangandan Indusiri Kecil dalam Pembangunan", LP3ES. Jakarta. 